ISSN 2519-2523 (print) Chornomors'ka mynuvshyna. -2019. - No.14.

DOI: $10.18524 / 2519-2523.2019 .14 .187131$

УДК 94(477) “1853/1868”

\title{
HISTORY OF OTTOMAN COSSACKS BY MATERIALS STATE OTTOMAN ARCHIVE (Başbakanlık Devlet Osmanlı Arşivi)
}

\section{Volodymyr Poltorak}

ORCID: https://orcid.org/0000 000304066907

Ph.D (History), Associate Professor

Odessa I.I. Mechnikov National University

2, Dvoryanska Str., Odessa, 65082, Ukraine

poltorak@onu.edu.ua

62 documents of 1853-1868 from the State Ottoman Archive (Istanbul, Turkey) cover the peculiarities of the formation, the battle path, the personal destiny of generals, officers and ordinary units of the Ottoman Cossacks. Most of the documents belong to the Amedi Foundation, the office of the highest governing bodies of the Ottoman Empire. These documents confirm the high level of accuracy of the memories of the head of the Ottoman Cossacks Mehmed Sadyk-Pasha (Michael Czaykowski) and somewhat clarify the dates and details of his biography. It is proved, that Sadyk-pasha was appointent as Dobrudja mutasarrif. Further search for documents on the history of the Cossacks in the Ottoman archives is still very perspective.

Key wards: Ottoman Cossacks, Mehmed Sdyk-pasha (Myhaylo Czajkowski), State Ottoman Archive (Başbakanlık Devlet Osmanlı Arşivi).

Володимир Полторак

ORCID: https://orcid.org/0000 000304066907

Кандидат історичних наук, доцент

Одеський національний університет імені І. І. Мечникова

Вум. Дворянська, 2, Одеса, 65082, Україна poltorak@onu.edu.ua

\section{ICTОРІЯ ОСМАНСЬКИХ КОЗАКІВ ЗА МАТЕРІАМАМИ ДЕРЖАВНОГО ОСМАНСЬКОГО АРХІВУ}

\author{
(Başbakanlık Devlet Osmanlı Arşivi)
}

62 документи 1853-1868 років з Державного Османського архіву (Стамбул, Туреччина) висвітлюють особливості утворення, бойовий шлях, особисту долю генералів, офічерів та рядових підрозділів османських козаків. Переважна частина документів належить до фонду Амеді - каниелярії вищих органів управління Османською імперією. Ці документи підтверджують високий рівень точності спогадів керівника османських козаків Мехмеда Садик-паші (Михайла Чайковського) та дещџ уточнюють дати $і$ подробииі його біографіï. Знаходить підтвердження факт призначення Садик-паші мутасарріфом Добруджі. Подальший пошук документів з історії козаитва в османських архівах залишається перспективним. 
Ключові слова: Османсъкі козаки, Мехмед Садик-паша (Михайло Чайковсъкий), Державний османсъкий архів (Başbakanlık Devlet Osmanlı Arşivi).

Мехмед Садик-паша (Михайло Чайковський) відомий як письменник, організатор та керівник так званих османських козаків ("казак-алай»), письменник та творець власної помітичної концепції розвитку східноєвропейських народів. Він вважав, що боротьба Польщі за незалежність потребує важливої підмоги - створення незалежної козацької держави на чомі з гетьманом. Його тридцятирічне перебування в Османської імперії стало періодом активних пошуків союзників у боротьбі з російським імперіалізмом. Одним з найбільших досягнень політика стало створення корпусу османських козаків в складі турецької армії.

Більшість досліджених документів щодо цього підроздіку походять 3 особистих фондів Садик-паші та з фонду Адама Чарторийського, який усіляко опікувався утворенням підроздіків османських козаків. Проте особливої уваги до турецьких архівів 3 боку істориків досі не спостерігалось. Дослідники з Туреччини Мустафа Гюмюш, Джандам Бадем та Саадет Бююк в своїх роботах посимаються на документи, проте не наводять аналізу їхнього інформаційного потенціалу в цілому. Завдячуючи пошукам професора Олени Бачинської у 2007 році були отримані переліки та описи документів в Başbakanlık Devlet Osmanlı Arşivi (дамі - ВОА), в цій публікації буде наведено їх анотації.

Серед матеріалів ВОА є передусім офіційні папери вищих органів управління Османською імперією. 62 документ, який віднайдені в архівосховищах та стосуються османських козаків, походять із 13 фондів, але переважна бімьшість - 3 відділів Фонду Амеді (канцемярії вищих органів управління). Подальші анотації документів буде наведено за фондами, де вони зберігаються, та за хронологічною ознакою. Один 3 документів на думку автора датований в архіві хибно і потребує уточнення час його укладення. Достатньо суперечиивою $є$ система датування документів - оскільки в Османській імперії паралельно використовувались декілька календарних систем, а основний Ісламський календар був незадовго до того реформований та перетворений на сонячний з початком в березні (т.зв. Румійський, тобто юліанський візантійський камендар). Відмік від Хіджри при цьому не був скасований. Частина документів датовані тільки роком, що викликає труднощі при визначені співвіднесення з григоріанським роком. В цій ситуації буде вказано обидва можливих григоріанські роки через знак “/”.Особлива подяка Олександру Середі за фахову консультацію.

10 документів 3 фонду Âmedî Kalemi Belgeleri (скорочено A.AMD) датуються періодом 23.09.1854-1856/1857 - тобто в основному періодом Східної (Кримської) війни.

Перші чотири документи датовані 1273 роком Хіджри - тобто припадають на 23.09.1854/12.09.1855. В них йдеться про призначення офіцерів першого та другого козацького полку (BOA. - A.AMD. - D.58/27. - 1 p.; A.AMD. - D.58/100. - 1 р.), про підвищення платні писарю Садикпаші - Хасибу-ефенді (BOA. - A.AMD. - D.58/97. - 1 р.), про спеціальне дослідження настроїв серед козаків, яке було проведене Ісмаїл-пашею $\mathrm{i}$ 
про можливість використати козаків в англійських інтересах (ВОА. A.AMD. - D.64/97. - 1 p.).

12 червня 1855 року датуються два документи - про затвердження нової адміністративної одиниці - мутасарріфата в складі двох округів (каймакамлиги казалар) - Добруджа та Тульча, а також про призначення на посаду, визначення окладу та надабавок жалування Добруджанського мутасарріфа Садик-паші (BOA. - A.AMD. - D.54/96. - 1 р.). Саме на цей час припадає інформація про бурхливу діяльність Садикпаші на нижньому Дунаї з підтримки старообрядців, зокрема зведення храмів у Тульчі та Вилковому.

10 серпня 1855 року командуючий козацькими полками Садикпаша був нагороджений орденом Меджидіє (BOA. - A.AMD. - D.55/18. 1 р.). Наступним 1273 (1855/1856) роком датується три документи 3 цього фонду - про відрядження Садик-бея, командуючого османськими козаками до Стамбулу (BOA. - A.AMD. - D.79/17. - 1 р.); про призначення та переїзд командира другого козацького полку графа Замойського та усіх бажаючих з цього підроздіку до Європи (ВОА. A.AMD. - D.79/84. - 1 p.; BOA. - A.AMD.- D.79/82. - 2 p.).

У фонді Sadâret Divan (Beylikçi) Kalemi Belgeleri (A.DVN) османських козаків стосуються два документи 1857 року. Перший датований 16 ^юто-го та стосується підвищення рангу писарю Садик-паші Хасибу-ефенді (ВОА. A.DVN. - D.121/25. - 1 р.), а в другому від 4 квітня 1857 року йдеться про призначення мірмірана (генерала) Садик-паші, командира османських козаків, Румелійським бейлербеєм (BOA. - A.DVN. - D.122/42. - 1 р.).

В фонді Sadaret Divân-ı Hümayûn Mühimme Kalemi Belgeleri (DVN.MHM) знайдено мише один документ, датований жовтнем 1857 року, в якому також, як і в попередньому йдеться про призначення Садик-паші бейлербеєм Румелії (BOA. - A.DVN.MHM. - D.21/91. - 1 р.).

В фонді Sadaret Mektubi Mühimme Kalemi (A. MKT.MHM) віднайдено 13 документів за період 1854-1868 років. Так, 17 грудня 1854 року датується звіт про виплату жалування козакам, які перебувають в підпорядкуванні Садик-паші (BOA. - А.MKT.MHМ. - D.757/77. - 1 р.). 3 травня 1855 року визначено необхідну кількість ячменю та пшениці 3 селищ Хавса та Кирккілісе, про підвищення платні Садик-паші (ВОА. A.MKT.MHM. - D.60/80. - 1 p.).

26 березня 1856 року виходить наказ про повторну виплату жалування писарю Садик-паші Хасибу-ефенді (BOA.- A.MKT.NZD. D.180/3. - 1 р.). А 14 ^ютого 1857 року на затвердження наказу про підвищення рангу, Хасиб-ефенді отримав відповідний документ про виплату жалування (BOA.- A.MKT.NZD. - D.207/19. - 1 р.).

16 жовтня 1857 року вже під час перебування двох полків в північній Греції, козаки отримали позитивні відгуки про іхню

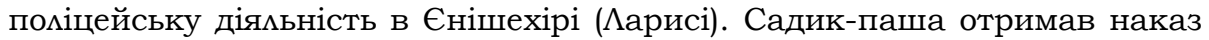
поїхати до адміністративного центру вілайету Яніни для аудієнції у губернатора області (BOA. - А.МКT.MHМ. - D.130/82. - 1 р.).

В документі від 10 грудня 1860 року йдеться про випмату Садикпаші двомісячного жалування (BOA. - A.MKT.MHM. - D.205/18. - 1 р.). 
24 мютого 1861 року виходить постанова про розслідування зцовживань Садик-пашею в якості губернатора Бухареста (1854 рік). Козацький командувач звинувачений у розтраті зібраних коштів (ВОА. A.MKT.MHM. - D.763/9. - 1 р.). 22 мипня 1861 року вийшиа постанова про надання Садик-паші особняка в районі Стамбула Бебек (Bebek), що до того належав Арапоглу Артіна (BOA. - A.MKT.MHM. - D.227/44. - 1 р.). 13 серпня 1861 року датується розписка про виплату Садик-паші компенсації за відрядження (BOA. - A.MKT.MHM. - D.225/78. - 1 р.). 27 вересня 1863 року Садик-паша подає запит на створення третього полку козаків та драгунів (BОА. - А.MKT.MHM. - D.378/41. - 1 р.).

Про подробиці дислокації козацько-драгунського корпусу на чомі 3 Садик-пашею в Едірне йдеться в документі, датованому 26 серпня 1868 року (BOA. - A.MKT.MHM. - D.421/44. - 1 р.). 7 вересня того ж року виходить наказ про поповнення скмаду козацько-драгунських полків під орудою Садик-паші (BOA. - A.MKT.MHM. - D.422/78. - 7 р.). 12 мистопада того ж року Садик-паша переслав до Стамбулу два мисти з Русе, які повідомияли про утворення в Бухаресті таємного комітету (ВОА. A.MKT.MHM. - D.426/48. - 5 p.).

Документ з фонду Sadaret Mektûbî Kalemi Meclis-i Vala (A.MKT.MVL), датований 18 квітня 1861 року, повідомляє про стан ведення господдарства в чифміку Теркос в передмісті Стамбулу (BOA. - A.MKT.MVL. D.126/46. - 1 p.). Як виходить 3 документу, там дислокувались підрозділи османських козаків, 3 інших документів відомо, що вже у 1856-1857 роках в казармах у Теркосі козаки дислокувались, там зафіксоване навіть поховання одного з офіцерів.

У фонді Sadâret Mektûbî Kalemi, Nezâret ve Devâir (A.MKT.NZD) бумо знайдено майже половину документів з ВОА - 25. Вони датуються 18531862 роками - тобто часом Кримської війни та перебування козаків у Греції.

4 грудня 1853 Мехмед Садик-ефенді отримав ранг мірміран-паші та військове звання мірліва, яке відповідає європейському рангу генералмайора (BOA. - A.MKT.NZD. - D.103/68. - 1 р.). Це відбулось відразу після утворення козацького полку та демонструє плани османського військового керівництва щодо створення козацької дивізії вже у 1853 році.

14 травня 1855 року жалування Садик-паші та його писарю було збільшено (BOA. - A.MKT.NZD. - D.148/27. - 1 р.). 15 червня Садик-паша, перебуваючи в Дерсаадеті (тобто, в Стамбумі, в “Воротах Щастя"), просить збімьшити термін перебування в місті (BOA. - A.MKT.NZD. D.151/62. - 1 p.). 5 мипня 1855 року командувач 2-м козацьким полком граф Замойський просить дозволу про відправлення до Парижу з метою забезпечити постачання полку амуніцією та озброєнням (BOA. - A.MKT.NZD. D.153/51. - 2 p.).

Наступний документ призначив розмір та порядок виплати жалування на 1273 рік (1856/1857) командувачу козаків Садик-паші та Катіп Нюжет-ефенді (BOA. - A.MKT.NZD. - D.215/35. - 1 р.). Цікавий документ датований 16 квітня 1857 року - він вказує на необхідність вцаштувати козаків на постій у Добруджі і доручає організувати його 
Садик-паші. Саме в цей час Садик-паша отримав призначення Румемійським бейлербеєм.

8 березня 1858 року датується розписка про погашення заборгованості Тахір-бея Садик-паші. Проте 23 березня того ж року виходить розписка аналогічного змісту, що напевно свідчить про часткове погашення заборгованості.

3 прохання Садик-паші від 26 грудня 1859 виходить, що частина козаків та драгунів з Шумена (тобто, болгар за походженням) не бажали перебувати в Єнішехірі (Аарисі) і просили перевести їх до Варни (ВОА. A.MKT.NZD. - D.296/55. - 1 p.).

Наступний документ 15 мистопада 1860 року містить прохання Садик-паші надати йому інший чифмік замість будинку в Сазми-босна (BOA. - A.MKT.NZD. - D.335/25. - 1 р.). Скоріш за все це пов'язане із згадуваним у спогадах Садик-паші випадком пожежі в його заміському будинку в Сазми-босні, що призвів до знищення його архівів, зокрема його історичних паперів з Волині. 5 грудня 1860 року відбулась виплата жалування Садик-паші (BOA. - A.MKT.NZD. - D.338/7. - 3 р.), а 28 квітня та 3 мипня йому була виплачена накопичена заборгованість по жалуванню (BOA. - A.MKT.NZD. - D.350/1. - 1 p.; BOA. - A.MKT.NZD. - D.357/8. 1 р.). В продовження справи надання Садик-паші помешкання в Стамбулі 2 травня 1861 року йдеться про участь в аукціоні щодо придбання будинку цирюльника Хюсню на вулиці Серенджебей в Бешикташі (BOA. - A.MKT.NZD. - D.350/46. - 1 р.), що неподалік від Йилдизпалацу. 11 травня 1861 року Садик-паша отримав чергову виплату жалування (BOA. - A.MKT.NZD. - D.352/16. - 1 р.) - можливо, це субсидія для придбання будинку, бо вже 20 травня Садик-паша отримує у власність особняк Арабоглу Артіна, що належав Казначейству (ВОА. A.MKT.NZD. - D.353/35. - 1 р.). Як виходить з одного із вищезгаданих документів, мише 22 мипня вийшло остаточне офіційне рішення щодо належності цього будинку Садик-паші. 25 мипня 1861 року був поданий запит англійця Сімона на купівлю чифміка, який належав Садик-паші напевне мається на увазі Сазли-босна (BOA. - A.MKT.NZD. - D.359/71. 1 р.). 11 мистопада 1861 року чифмік Садик-паші був переданий новому господарю, при цьому в документах помилково згадується про новий ранг Садик-паші - Ферік (генерал-цейтенант в європейські системі) (BOA. - A.MKT.NZD. - D.378/1. - 1 p.).

Саме в цей час відбувається зміна імператора на престолі і султаном стає Абдул-Азіз. 3 документа від 3 мипня 1861 року виходить, що Садика паша в якості козацького командувача був призначений до церемоніального підрозділу Таклід-Сейф ("Опоясування мечем" - аналог коронації європейських монархів) (BOA. - A.MKT.NZD. - D.357/12. - 1 р.).

17 ^ютого 1862 року Садик-паша отримав відпустку через хворобу та для завершення написання мітературних творів. Він відправцяється в Стамбул (Дерсаадет) (BOA. - A.MKT.NZD. - D.400/83. - 1 р.). 19 цютого 1862 призначений новий командувач козацьких полків на час відпустки Садик-паші (BOA. - A.MKT.NZD. - D.401/54. - 2 р.). 
4 травня 1862 року знов піднято питання про підтвердження призначення Садик-паші рангу феріка (генерал-цейтенант) та нового посадового окладу як одного із мірміранів (бейлербеїв) Румелії (тобто, губернатор Добруджі) (BOA.- A.MKT.NZD.- D.416/40.- 1 р.). 26 травня щодо цього питання винесене неоднозначне рішення - зарплатню Садик-паші не підвищувати (BOA.- A.MKT.NZD.- D.421/22.- 1 р.) і ранг Ферік не надавати. I нарешті 21 червня 1862 року завдяки участі в рішенні сербського питання, покровительству командувача кавалерійсь-

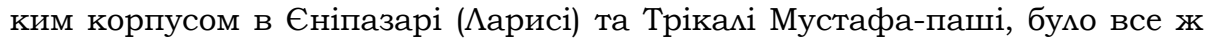
винесене рішення про надання Садик-паші - командиру драгунського полку - рангу Ферік (BOA. - A.MKT.NZD. - D.426/37. - 1 р.).

У фонді Sadâret Mektubi Kalemi-Umum Vilayat (A.MKT.Um.) віднайдено два документи. В першому від 2 березня 1855 року виголошується подяка командиру козацького полку Садик-паші за його успішні дії (BOA. - A.MKT.MHM. - D.180/45. - 2 р.). А в другому від 18 жовтня 1860 року йдеться про те, що мутасарріф Пцовдіва Ахмед Азіз отримав повідомкення про нагородження від Садик-паші під час перебування в Приштіні (BOA. - A.MKT.UM. - 432/44. - 1 р.).

3 фонду Hariciye Nezareti Mektubi Kalemi Evrakı (HR.MKT) знайдено три документи з періоду становцення османських козаків. 17 мистопада 1853 року надіслано прохання Хусейна Хасіба-ефенді про набір рядових до козацького полку Садик-паші (ВОА. - HR.MKT. - 67/3. - 1 р.). 20 жовтня 1854 датується звіт про доставку одягу та амуніції до козацького полку Садик-паші (BOA. - HR.MKT. - D.91/8. - 1 р.). 14 грудня Мірміран Садик-паша повідомив про труднощі щодо створення другого козаць-кого полку і відкладення цього (BOA. - HR.MKT. D.95/46. - 3 p.).

У фонді палацу Йилдиз Yildiz Esas Evraki (Y.EE) зберігається прохання щодо обмеження прийому Садик-пашею перебіжчиків поляків до козацького полку (BОА. - Y.ЕЕ. - D.41/65. - 1 р.). Можииво це пов'язано з побоюваннями щодо їх вірності та розслідуванням, яке проведено Ісмаїл-пашею (див. вище).

Фонд Irade Eyalet-i Mümtaze Yunanistan (I.MTZ.(01)) містить документ від 18 січня 1858 року про надання необхідної допомоги Садик-пашеві від губернатора Яніни та румелійського головнокомандувача у зв'язку 3 передислокацією козацького полку та трьох ескадронів драгунів на грецький кордон Османської імперії (BOA. - I.MTZ.(01). - 13/337. - 8 р.).

Ще один документ, датований 20 березня 1861 року, містить фонд Irade Meclis-i Vala (I.MVL). В наказі йдеться про необхідність надати Садикпаші будинок за державний кошт (BOA. - I.MVL. - 446/19852. - 8 р.).

26 березня 1864 року командиру козацького полку Садик-паші було призначено пенсію (atiyye ) - про це йдеться в Указі із фонду İrade Meclis-i Mahsus (I.MMS) (BOA. - I.MMS. - D.28/1209. - 11 p.).

У фонді Irade Hariciye (I..HR..) міститься два укази - від 23 травня 1855 року про надання думок Садик-паші щодо козацької організації Тимчасовим зборам (BOA. - I.HR. - D.120/5958. - 2 р.) та від 22 Аипня 
1855 про встановлення зарплатні писарю Садик-паші Хабіб-ефенді (BOA. - I.HR. - D.122/6102. - 2 p.).

Таким чином, в документах Державного Османського Архіву (BOA) можемо простежити зміну статусу козацьких підрозділів, переміщення їх в Добруджу, на кордони Греції, на Балканський півострів. Дуже докладно в документах проявляється питання жалування та надання житла командувачу османськими козаками Мехмеду Садик-паші. Знаходять підтвердження дані, надані Садик-пашею в спогадах, опублікованих наприкінці XIX століття в "Русской старине». Завдяки цим докментам можна уточнити хронологію та географію перебування козацьких підрозділів та їхнього командувача, визначити їхню роль у внутрішньо-політичних процесах в Османській імперії.

\section{Джерела та література:}

1. Badem, Candan. The Ottoman Crimean War (1853-1856). - Leidem-Boston, 2010.

2. Gümüs Musa. Mehmed Sadik Pasa (Michal Czajkowski) ve Osmanli devlet'nde kazak suvari alayi // Turkish studies. - V. 5/3. - 2010. - P.1362-1375.

3. Saadet Büyük. Michał Czajkowski (Sadik Pasha) and his cossack cavalry regiment/ In Partial Fulfilment of the Requirements for the Degree of master of arts. - Ankara, 2013. - 135 p.

\section{References:}

1. Badem, Candan (2010). The Ottoman Crimean War (1853-1856). LeidemBoston. [in English].

2. Gümüs Musa (2010). Mehmed Sadik Pasa (Michal Czajkowski) ve Osmanli devlet'nde kazak suvari alayi: Turkish studies. V. 5/3. 2010. [in Turkish].

3. Saadet Büyük (2013). Michał Czajkowski (Sadik Pasha) and his cossack cavalry regiment/ In Partial Fulfilment of the Requirements for the Degree of master of arts. Ankara. [in Turkish].

Владимир Полторак ORCID: https://orcid.org/0000 000304066907 Кандидат исторических наук, доцент Одесский национальный университет имени И.И. Мечникова УА. Дворянская, 2, Одесса, 65082, Украина poltorak@onu.edu.ua

\section{История османских казаков по материалам Государственного Османского архива (Başbakanlık Devlet Osmanlı Arşivi)}

62 документа 1853-1868 годов из Государственного Османского архива (Стамбул, Туриия) освещают особенности образования, боевой путь, личную судъбу генералов, офииеров и рядовых подразделений османских казаков. Большинство документов относится к фонду Амеди - канцелярии высших органов управления Османской империей. Эти документы подтверждают высокий уровень точности воспоминаний руководителя османских казаков Мехмеда Садык-паши (Михаила Чайковского) и несколько уточняют даты и подробности его биографии. Находит подтверждение факт назначения 
Садык-паши мутасаррифом Добруджи. Дальнейший поиск документов по истории казачества в османских архивах остается перспективным.

ключевые слова: Османский казаки, Мехмед Садык-паша (Михаил Чайковский), Государственный Османский архив (Başbakanlık Devlet Osmanlı Arşivi).

Отримано:12.12.2019p. 